\title{
POTENSI SUPLAI LIMBAH KELAPA SAWIT SEBAGAI PEWARNA ALAM KAIN SASIRANGAN : ISU DAN PENGEMBANGAN
}

\author{
Rianti Indah Lestari \\ Jurusan Teknik Industri, Fakultas Sains dan Teknologi, Universitas Sari Mulia \\ Jalan Pramuka No.2, Banjarmasin, Kalimantan Selatan \\ Email : riantyindah29@gmail.com
}

\begin{abstract}
Abstrak-Seiring berkembangnya industri fashion di Indonesia tidak terlepas dari peran pelaku ekonomi kreatif dalam mengembangkan potensi kain tradisional dalam upaya pelestarian warisan budaya nasional. Perkembangan kain tradisional yang diminati semua kalangan baik dari desain maupun warna nya menjadi isu utama untuk penerapan produk yang berkelanjutan khususnya pemanfaatan produk ramah lingkungan. Kain sasirangan yang merupakan kain tradisional dari Kalimantan Selatan juga berpotensi untuk memproduksi kain yang ramah lingkungan. Tujuannya adalah untuk mengurangi pencemaran lingkungan akibat penggunaan zat warna kimia. Pada penelitian ini mengulas potensi cangkang kelapa sawit sebagai salah satu limbah perkebunan kelapa sawit yang digunakan untuk bahan baku utama pembuatan zat warna alam. Ketersediaan zat warna alam tidak lepas dari informasi terkait potensi jumlah cangkang kelapa sawit yang ada di Kalimantan Selatan. Selain itu untuk keberlanjutan penelitian diperlukan struktur rantai suplai bahan baku yaitu Supply Chain Operation Model in terms of Raw Material (SC-OPMRM) sebagai model untuk perancangan jaringan suplai.
\end{abstract}

Kata Kunci : Kain Sasirangan, Ramah lingkungan, Zat warna alam, Cangkang kelapa sawit, SC-OPM_RM.

\section{PENDAhuluan}

Usaha Mikro Kecil dan Menengah (UMKM) memiliki peran besar terhadap perekonomian negara, tak terkecuali bagi perekonomian daerah. Dalam hal ini peran pemerintah daerah sangat dibutuhkan untuk pengembangan UMKM. Beberapa jenis UMKM telah banyak diminati masyarakat baik di kalangan tua maupun muda yaitu diantaranya usaha kuliner, usaha fashion, usaha furniture, usaha elektronik, bahkan ada juga yang melirik usaha di bidang jasa seperti jasa perbaikan barang-barang eletronik, penyewaan kostum, serta fotografi. Di antara banyaknya UMKM yang bermunculan, usaha fashion kain tradisional menjadi salah satu trend bagi para pelaku ekonomi kreatif di Indonesia. Ketertarikan pada pemilihan kain tradisional bukan hanya mengedepankan tujuan memperoleh keuntungan namun juga sebagai upaya dalam melestarikan warisan budaya daerah.

Salah satu warisan budaya masyarakat, khususnya yang ada di Kalimantan Selatan yaitu kain sasirangan yang merupakan kain khas setempat. Pembuatan kain sasirangan umumnya dimulai dari tahap membuat desain motif, merajut, mencelup, membuka rajutan, mencuci, dan menyetrika. Di samping pembuatan kain sasirangan yang rumit, motif serta warnanya yang mencolok juga menjadi keunikan tersendiri bagi peminat kain ini baik warga asli suku banjar maupun wisatawan. Sebagai salah satu bentuk keseriusan pemerintah provinsi Kalimantan Selatan untuk mempromosikan produk unggulan, maka dibentuklah kawasan khusus sasirangan yang diberi nama kampung sasirangan [8]. Kawasan tersebut selain sebagai pusat penjualan juga merupakan sentra produksi pembuatan kain sasirangan. Selain itu upaya pelestarian serta promosi ini juga sejalan dengan surat edaran dari pemerintah kota Banjarmasin yang menghimbau pegawai di lingkungan kerjanya untuk mengenakan pakaian sasirangan setidaknya sekali dalam sebulan [3]. Bukan hanya itu, kain sasirangan yang dipakai adalah sasirangan ramah lingkungan yaitu yang menggunakan pewarna alami. Hal ini menjadi penting karena masih maraknya penggunaan pewarna kimia dalam proses pencelupan kain. Kurangnya tempat pembuangan limbah serta pengolahannya merupakan masalah utama penyebab pencemaran lingkungan, bahkan tidak sedikit yang membuangnya ke sungai. Padahal jika dilihat dari potensinya sebagai salah satu penyumbang perekonomian, industri kain sasirangan merupakan salah satu usaha yang keberadaannya tergolong sustainable (berkelanjutan) karena peminatnya yang berasal dari semua kalangan.

Oleh karena itu, sejalan dengan konsep pembangunan yang berkelanjutan serta pemanfaatan produk yang ramah lingkungan, para pengrajin kain sasirangan diharapkan mampu berkontribusi dalam upaya mengurangi pencemaran lingkungan. Di samping itu pemanfaatan sumber-sumber pewarna alami merupakan salah satu bahan utama yang penting digunakan dalam proses pencelupan kain. Keberlanjutan produksi kain sasirangan ini tidak lepas dari peran stakeholder di level upstream (hulu) dan customer di level downstream (hilir). Rangkaian suatu aktivitas industri dari hulu ke hilir tidak terlepas dari konsep supply chain (rantai pasok) yaitu jaringan pemasok, pabrik, distributor utama, dan pengecer, di mana bahan baku diperoleh, diubah, diproduksi, dan dikirim ke pelanggan [7]. Selain itu rantai pasok merupakan jaringan perusahaan-perusahaan yang berintegrasi bersama untuk menciptakan dan mengirimkan produk kepada customer [9]. Agar proses produksi dapat terus berjalan, maka ketersediaan bahan baku pewarna alami harus terpenuhi.

Salah satu bahan baku penyuplai pewarna alami yang potensial khususnya di Kalimantan Selatan yaitu limbah perkebunan yaitu cangkang kelapa sawit. Pemanfaatan limbah kelapa sawit ini bertujuan untuk mengurangi pencemaran lingkungan serta proses transformasi dari limbah menjadi produk yang dapat bernilai tambah. Limbah perkebunan merupakan sisa hasil proses pengolahan yang merupakan hasil 
sampingan yang dianggap berpotensi menjadi penyumbang pencemaran lingkungan [10].

\section{PELUANG PENELITIAN RANTAI PASOK PEWARNA ALAM}

\subsection{Peluang Penelitian Rantai Pasok Pewarna Alam}

Adapun penelitian yang telah dilakukan terkait bahan baku yang digunakan untuk pewarna alami yaitu dapat dilihat pada Tabel 1 .

Tabel 1. Bahan baku pewarna alami

\begin{tabular}{|l|l|}
\hline \multicolumn{1}{|c|}{ Bahan baku } & \multicolumn{1}{|c|}{ Warna yang dihasilkan } \\
\hline Red Sandalwood, & Merah, Orange, Kuning, \\
Madder, Safflower, & Biru, Hijau, Ungu, Hijau \\
Turmeric, Harda, & Tua \\
Berberis, Mulberry, & \\
Indigo, Alkanet, Jamun, & \\
Basil, Onion peel, \\
Spinach, Heena, Hibiscus & \\
[2] [11] & \\
\hline Cangkang kelapa sawit; & $\begin{array}{l}\text { Cokelat muda sampai } \\
\text { kakao [10] }\end{array}$ \\
& cokelat tua; abu-abu \\
\hline Morinda Lucida [5] & Hijau kekuningan \\
\hline
\end{tabular}

\subsection{Sebaran Lahan Kelapa Sawit Di Kalimantan Selatan}

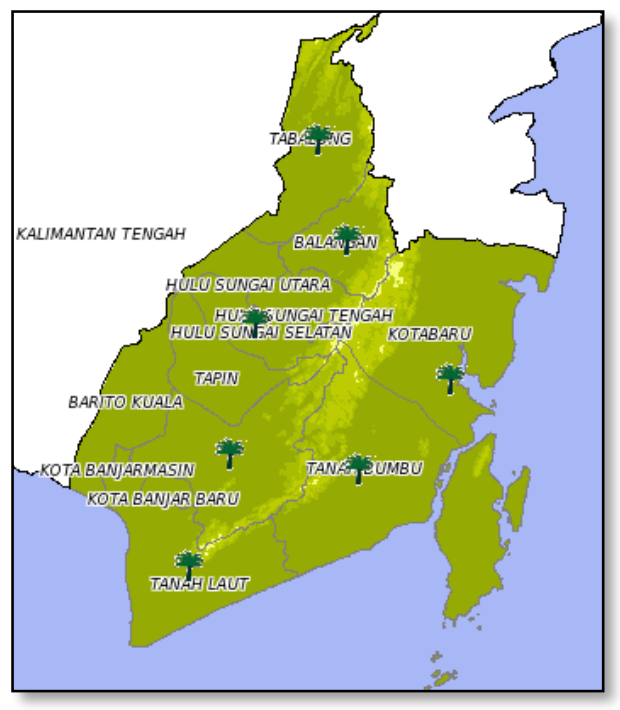

Gambar 2. Peta sebaran lahan kelapa sawit Provinsi Kalimantan Selatan 2011

Peta sebaran lahan kelapa sawit disusun menurut kabupaten/kota sehingga dapat diketahui area perkebunan kelapa sawit yang ada di Kalimantan Selatan (Gambar 2.) sedangkan pada Tabel 3. merupakan luas area perkebunan menurut kabupaten/kota yaitu Perkebunan Rakyart (PR), Pemerintah (PTPN), dan Perkebunan Besar Swasta (SWASTA) [12]
Tabel 2. Luas area perkebunan

\begin{tabular}{|r|l|r|r|r|r|r|r|r|r|}
\hline No & KABUPATEN & \multicolumn{1}{c|}{ PR } & \multicolumn{1}{c|}{$\%$} & \multicolumn{1}{l}{ PTPN } & \multicolumn{1}{c}{$\%$} & SWASTA & \multicolumn{1}{c|}{$\%$} & JUMLAH & SAPI \\
\hline 1 & TANAH LAUT & 7.237 & 8,35 & 3.365 & 3,88 & 76.061 & 87,77 & 86.663 & 315 \\
\hline 2 & KOTA BARU & 18.362 & 13,74 & 1.500 & 1,12 & 113.752 & 85,13 & 133.614 & 41 \\
\hline 3 & BANJAR & 860 & 10,29 & 0 & 0,00 & 7.500 & 89,71 & 8.360 & 0 \\
\hline 4 & BARITO KUALA & 368 & 5,21 & 0 & 0,00 & 6.692 & 94,79 & 7.060 & 0 \\
\hline 5 & TAPIN & 150 & 2,48 & 0 & 0,00 & 5.890 & 97,52 & 6.040 & 0 \\
\hline 6 & $\begin{array}{l}\text { HULU SUNGAI } \\
\text { SELATAN }\end{array}$ & 1.918 & 39,00 & 0 & 0,00 & 3.000 & 61,00 & 4.918 & 0 \\
\hline 7 & $\begin{array}{l}\text { HULU SUNGAI } \\
\text { TENGAH }\end{array}$ & 0 & 0,00 & 0 & 0,00 & 0 & 0,00 & 0 & 0 \\
\hline 8 & $\begin{array}{l}\text { HULU SUNGAI } \\
\text { UTARA }\end{array}$ & 10 & 0,65 & 0 & 0,00 & 1.520 & 99,35 & 1.530 & 0 \\
\hline 9 & BALANGAN & 420 & 19,81 & 0 & 0,00 & 1.700 & 80,19 & 2.120 & 0 \\
\hline 10 & TABALONG & 815 & 11,34 & 0 & 0,00 & 6.374 & 88,66 & 7.189 & 0 \\
\hline 11 & TANAH BUMBU & 24.260 & 44,05 & 0 & 0,00 & 30.815 & 55,95 & 55.075 & 39 \\
\hline 12 & BANJARBARU & 150 & 100,00 & 0 & 0,00 & 0 & 0,00 & 150 & 0 \\
\hline 13 & BANJARMASIN & 0 & 0,00 & 0 & 0,00 & 0 & 0,00 & 0 & 0 \\
\hline $\begin{array}{l}\text { KALIMANTAN } \\
\text { SELATAN }\end{array}$ & $\mathbf{5 4 . 5 5 0}$ & $\mathbf{1 7 , 4 4}$ & $\mathbf{4 . 8 6 5}$ & $\mathbf{1 , 5 6}$ & $\mathbf{2 5 3 . 3 0 4}$ & $\mathbf{8 1 , 0 0}$ & $\mathbf{3 1 2 . 7 1 9}$ & $\mathbf{3 9 5}$ \\
\hline
\end{tabular}

Dari Tabel 2. dapat dilihat bahwa terdapat sebesar 312,79 ha lahan kelapa sawit yang ada di Kalimantan Selatan. Satu hektar luas lahan perkebunan kelapa sawit berpotensi menghasilkan 16,1 ton tandan kelapa sawit segar dan menghasilkan limbah sawit berupa pelepah, batang, tandan kosong kelapa sawit, serat dan cangkang kelapa sawit yang jumlahnya masing-masing sebanyak 13,2 ton; 1,4 ton; 3,7 ton; 1,9 ton; dan 1,6 ton.

Menurut [6], ketersediaan sektor perkebunan kelapa sawit yang melimpah berdampak signifikan terhadap potensi pengembangan produk samping dan limbah kelapa sawit di Kalimantan Selatan terlebih jika dapat digunakan sebagai bahan baku pewarna alam.

\subsection{Struktur Rantai Suplai Bahan Baku}

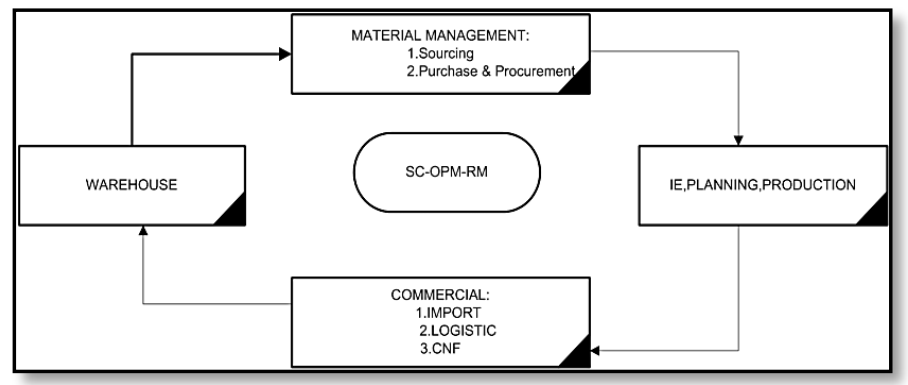

Gambar 1. Supply Chain Operation Model in terms of Raw Material (SC-OPM-RM) [1]

Berdasarkan Gambar 1 dapat diperoleh bahwa terdapat beberapa kategori area rantai pasok bahan baku dalam industri pakaian jadi yaitu diantaranya dapat dijelaskan pada Tabel 3 .

Tabel 3. Aktivitas Utama Kategori Rantai Pasok Bahan Baku

\begin{tabular}{|c|l|l|}
\hline No & \multicolumn{1}{|c|}{ Kategori Area } & \multicolumn{1}{|c|}{ Aktivitas Utama } \\
\hline 1 & $\begin{array}{l}\text { Material Management } \\
\text { (Manajemen Bahan } \\
\text { Baku) }\end{array}$ & $\begin{array}{l}\text { Identifikasi sumber } \\
\text { pemasok, pemesanan } \\
\text { sampel, negosiasi } \\
\text { pembelian, konfirmasi }\end{array}$ \\
\hline
\end{tabular}




\begin{tabular}{|c|l|l|}
\hline & & $\begin{array}{l}\text { harga, waktu tunggu, } \\
\text { syarat dan ketentuan, } \\
\text { Penerimaan sampel } \\
\text { bahan baku, }\end{array}$ \\
\hline 2 & $\begin{array}{l}\text { Industrial Engineering } \\
\text { (IE), Planning, } \\
\text { Production (Teknik } \\
\text { Industri, Perencanaan, } \\
\text { Produksi) }\end{array}$ & $\begin{array}{l}\text { Pembuatan jadwal } \\
\text { perencanaan produksi ke } \\
\text { manajemen bahan baku, } \\
\text { membantu pemenuhan } \\
\text { tanggal pengiriman }\end{array}$ \\
\hline $\begin{array}{l}\text { Commercial (Aliran } \\
\text { Produk) }\end{array}$ & $\begin{array}{l}\text { Melanjutkan pembayaran } \\
\text { pesanan, konfirmasi } \\
\text { kepada manajemen } \\
\text { bahan baku dan logistik, } \\
\text { Pengecekan aliran } \\
\text { material bahan baku dari } \\
\text { pemasok ke } \text { end } \\
\text { customer, perencanaan } \\
\text { pengadaan dan } \\
\text { pembelian bahan baku, } \\
\text { manajemen biaya (biaya } \\
\text { bahan baku, biaya } \\
\text { pengadaan, biaya } \\
\text { transportasi) }\end{array}$ \\
\hline & $\begin{array}{l}\text { Parehouse } \\
\text { (Penyimpanan) }\end{array}$ & $\begin{array}{l}\text { Pemberian laporan stok } \\
\text { kepada manajemen } \\
\text { bahan baku, pemberian } \\
\text { informasi pesanan } \\
\text { kepada supplier } \\
\text { pemberian label } \\
\text { persediaan dengan benar } \\
\text { dan tepat, pemeriksaan } \\
\text { kualitas bahan baku }\end{array}$ \\
\hline & & \\
& & \\
& &
\end{tabular}

\section{KESIMPULAN}

1. Berdasarkan peta sebaran jumlah produksi kelapa sawit di Kalimantan Selatan berpotensi menghasilkan limbah cangkang kelapa sawit yang jumlahnya besar sehingga berpeluang sebagai bahan baku pembuatan zat warna alam untuk digunakan sebagai pewarna kain sasirangan

2. Pada model SC-OPM-RM terdapat beberapa kategori area beserta aktivitas utama pada pengelolaan bahan baku.

\section{SARAN}

Adapun saran untuk penelitian selanjutnya yaitu sebagai berikut:

1. Belum adanya penelitian terkait berapa jumlah konversi cangkang kelapa sawit sehingga menghasilkan zat warna alam.

2. Perlunya penambahan sebaran jumlah perajin kain sasirangan yang berpotensi memproduksi kain sasirangan dengan menggunakan pewarna alami.

3. Jumlah bahan baku yang besar memungkinkan untuk dapat dilakukan penelitian mendalam terkait perancangan jaringan rantai suplai untuk bahan baku pembuatan zat warna.

\section{DAFTAR PUSTAKA}

[1] Akter.M, Uddin.H.M, 2017, Supply Chain Operation Model in Terms of Raw Material in Bangladesh Apparel Industry, International Journal of Textile Science, Vol 6

[2] Arora.J, Agarwal.P, Gupta.G, 2017, Rainbow of Natural Dyes on Textiles Using Plants Extracts: Sustainable and Eco-Friendly Processes, Green and Sustainable Chemistry, Vol 1

[3] Banjarmasin Post., 2019, Supaya Perajin Sasirangan Tak Cemari Lingkungan, Ini Solusi dari Walikota Banjarmasin, http://banjarmasinpost.co.id/, (diakses pada 07 Februari 2020)

[4] Elykurniati, 2011, Pemanfaatan Limbah Padat Cangkang Kelapa Sawit Dalam Pembuatan Pupuk Cair Kalium Sulfat, http://eprints.upnjatim.ac.id/, (diakses pada 07 Februari 2020)

[5] Janani.L, 2015, Dye for the Future: Natural Dye from Morinda Lucida Plant for Cotton and Silk Fabrics, International Journal of Research \& Review, Vol 2

[6] Nadia.A, Sunardi.S, 2017, Potensi Limbah Lignoselulosa Kelapa Sawit Di Kalimantan Selatan Untuk Produksi Bioetanol Dan Xylitol, Jurnal Inovasi Pendidikan Sains, Vol 8

[7] Nema.N, Talankar.A., Soni.R.S, Nougriaya.S, 2013, Green Supply Chain Management Practices In Textile And Apparel Industries: Literature Review, International Journal Of Engineering Technology\& Management Research, Vol 1

[8] Pratomo.A, Najwaini.E, Irawan.A, Risa.M, 2018, Optimasi ECommerce Dengan Penerapan Teknik SEO (Search Engine Optimization) Untuk Meningkatkan Penjualan Pada UKM Nida Sasirangan, Jurnal Impact: Implementation and Action, Vol 1

[9] Pujawan.N.I, 2005, Supply Chain Management, Guna Widya

[10] Pujilestari.T, Farida, Pristiwati.E, Atika.V, Haerudin.A, 2016, Pemanfaatan Zat Warna Alam Dari Limbah Perkebunan Kelapa Sawit Dan Kakao Sebagai Bahan Pewarna Kain Batik, Dinamika Kerajinan dan Batik, Vol 33

[11] Samantha.K.A, Agarwal.P, 2009, Application Of Natural Dyes On Textiles, Indian Journal Of Fibre \& Textile Research, Vo 34

[12] Setiadi.B, Diwyanto.K, Puastuti.W, Mahendri.P.A.G.I, Tiesnamurti.B, 2011, Peta Potensi dan Sebaran Areal Perkebunan Kelapa Sawit di Indonesia, Sistem Integrasi Sapi-Kelapa Sawit (SISKA), Badan Penelitian dan Pengembangan Pertanian, Kementerian Pertanian 